Shifting paradigms in the assessment of recreational water quality http://dx.doi.org/10.1016/..watres.2010.07.061

(c) 2010 Elsevier Ltd All rights reserved.

\title{
Development of microbial and chemical MST tools to identify the origin of the faecal pollution in bathing and shellfish harvesting waters in France
}

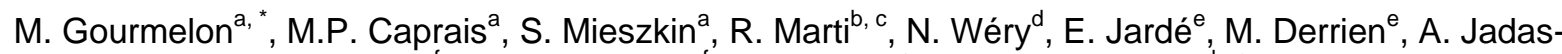 \\ Hécart $^{f}$, P.Y. Communal ${ }^{f}$, A. Jaffrezic ${ }^{g}$ and A.M. Pourcher ${ }^{b, c}$ \\ a Ifremer, EMP, Laboratoire de Microbiologie, Plouzané, France \\ ${ }^{b}$ Cemagref, Rennes, France \\ ${ }^{c}$ Université Européenne de Bretagne, Rennes, France \\ d INRA, Laboratoire de Biotechnologie de l'Environnement, Narbonne, France \\ e CNRS Géosciences Rennes, France \\ ${ }^{\dagger}$ Université d'Angers, France \\ g INRA AgroCampus, Rennes, France \\ *: Corresponding author: M. Gourmelon, Tel.: +33 2982245 76; fax: +33 2982245 94, email address : \\ Michele.Gourmelon@ifremer.fr
}

\begin{abstract}
:
The microbiological quality of coastal or river waters can be affected by faecal pollution from human or animal sources. An efficient MST (Microbial Source Tracking) toolbox consisting of several hostspecific markers would therefore be valuable for identifying the origin of the faecal pollution in the environment and thus for effective resource management and remediation. In this multidisciplinary study, after having tested some MST markers on faecal samples, we compared a selection of 17 parameters corresponding to chemical (steroid ratios, caffeine, and synthetic compounds), bacterial (host-specific Bacteroidales, Lactobacillus amylovorus and Bifidobacterium adolescentis) and viral (genotypes I-IV of F-specific bacteriophages, FRNAPH) markers on environmental water samples $(n=33$; wastewater, runoff and river waters) with variable Escherichia coli concentrations. Eleven microbial and chemical parameters were finally chosen for our MST toolbox, based on their specificity for particular pollution sources represented by our samples and their detection in river waters impacted by human or animal pollution; these were: the human-specific chemical compounds caffeine, TCEP (tri(2-chloroethyl)phosphate) and benzophenone; the ratios of sitostanol/coprostanol and coprostanol/(coprostanol+24-ethylcopstanol); real-time PCR (Polymerase Chain Reaction) humanspecific (HF183 and B. adolescentis), pig-specific (Pig-2-Bac and L. amylovorus) and ruminantspecific (Rum-2-Bac) markers; and human FRNAPH genogroup II.
\end{abstract}

Keywords: Microbial source tracking; Faecal pollution; Bacteroidales; Bifidobacterium adolescentis; Lactobacillus; FRNA bacteriophages; Steroids; Caffeine 


\section{Introduction}

Human and animal faecal pollution may affect inland and coastal water with negative effects on recreational uses, public safety or shellfish sanitary status (Feldhusen 2000; Dorfman and Sinclair Rosselot 2008) and can lead to economic losses due to shellfish bed closures or bathing prohibition (Rabinovici et al., 2004).

In order to improve water quality, management and remediation plans need methods of identifying faecal pollution sources. Indeed, the introduction of the Water Framework Directive (WFD, 2000/60/EC) in the EU has provided a framework for integrated water management by river basin, and this requires the consideration of point- or diffuse-pollution sources. More especially, one of its daughter directives, the revised Bathing Water European Directive (2006/7/EC), sets more stringent microbiological quality targets and requires that Member States establish bathing water profiles that assess pollution risks. These profiles are an inventory and study of the pollution sources likely to affect water quality, and are drawn up for each bathing water zone. In addition, the revised EU Shellfish Directive (Hygiene 3 Regulation $\left.\mathrm{N}^{\circ} 854 / 2004\right)$ goes through the best means of assessment for potential faecal pollution sources upstream of shellfish farming areas.

A major shortcoming of such evaluations at present is that the faecal microbiological indicators used as standards in these regulations i.e. Escherichia coli and enterococci cannot distinguish between human and animal faecal pollution. As identification of nonpoint-source or multiple pollutions is difficult, Microbial Source Tracking (MST) methods have been developed to discriminate between human and nonhuman sources of faecal pollution, and between different animal species. Microbial or chemical targets associated with human and animal faeces, or their related effluents, have been proposed (Glassmeyer et al., 2005; US EPA 2005; Field and Samadpour 2007). For example, chemical markers such as faecal steroids (Leeming et al., 1996; Shah et al., 2007; Tyagy et al., 2007), caffeine and synthetic compounds released into urban wastewaters (Glassmeyer et al., 2005) have been used to distinguish human and animal pollution. Microbial markers including bacteria, Archaebacteria, viruses and protozoa have also been tested (Bernhard and Field 2000; Jimenez-Clavero et al., 2003; Ufnar et al., 2007).

Until now, no single source tracking microbial or chemical method appears sufficiently discriminatory to identify the origin of faecal pollution in water (Griffith et al., 2003; Blanch et al., 2006; Field and Samadpour, 2007). Although a MST toolbox combining several methods could potentially improve discrimination, only a few studies have been done to develop and compare the combination of several MST methods (Griffith et al., 2003; Blanch et al., 2006; Ahmed et al., 2007; McQuaig et al., 2009).

Given the few data available on combined chemical and microbial source tracking methods, a multidisciplinary study was conducted by six French research Institutes in order to propose an efficient MST toolbox that could differentiate human, pig and bovine pollution in surface waters. In fact, even though pollution from pets, horses and wild animals such as waterfowl birds could contribute to faecal pollution of waters (Savichtcheva et al., 2007; Lu et al., 2008), human wastes (WWTP discharges, autonomous sanitation systems effluents, or sewage sludge spreading), and agricultural runoff containing faecal pollution from pig and bovine manure spreading and pasture are more often responsible for pollution in catchments in France, which is the top cattle producer and the third largest pig producer in the EU.

In the first phase of this project, each laboratory independently developed and validated its chemical or microbial methods on faeces, manure and wastewater treatment plant (WWTP) effluents.

Chemical markers investigated in this study included i) caffeine and seven synthetic compounds selected from the 35 compounds proven useful as indicators of anthropogenic pollution in the largest study performed to date (Glassmeyer et al. 2005), and ii) faecal sterol and stanol fingerprints, which have been widely used to monitor faecal pollution in water and to distinguish human and animal sources (Leeming et al., 1996; Shah et al., 2007). 
The microbiological approach, which included viral and bacterial markers, was based on library-independent methods. The viral markers tested were F-specific RNA bacteriophages (FRNAPH); these have been classified into four genogroups, two of which (II, and III) predominate in WWTP effluents, and two of which (I and IV) are mainly associated with animal faeces and effluents (Schaper et al., 2002; Ogorzaly et al., 2006). Bacterial markers were selected among Bacteroidales and Bifidobacterium, two bacterial groups that have been reported to contain host-specific bacterial species (Bernhard and Field, 2000; Delcenserie et al., 2004; Dick et al., 2005; Lamendella et al., 2008). The human-specific Bacteroidales HF183, first described by Bernhard and Field (2000) and modified for real-time PCR assay by Seurinck et al. (2005), was selected due to its high specificity (Mieszkin et al., 2010). Three other Bacteroidales (two pig-specific and one ruminant-specific) markers were selected according to the results of a previous analysis of 16S rRNA Bacteroidales gene sequences of animal faeces and effluents (Mieszkin et al., 2009). A third pig-specific marker, Lactobacillus amylovorus, which has been successfully tested by Marti et al. (2010), was also selected. Finally, a phylotype related to Bifidobacterium adolescentis was chosen that had been identified as a potential human marker after analyzing the diversity of bifidobacteria in treated WWTP effluents, although its specificity had not been tested (Wéry et al., 2010). Our aims were therefore (i) to select and test chemical markers, FRNAPH and $B$. adolescentis on faeces and effluent samples; (ii) to evaluate the efficiency of a new toolbox composed of these markers, Bacteroidales markers and $L$. amylovorus, for differentiation of human and livestock faecal pollution, by analyzing wastewaters, runoff waters and rivers; and (iii) to select the most effective set of markers for identifying the origin of faecal pollution.

\section{Materials and methods}

\subsection{Adaptation and testing of existing methods on faecal samples}

\subsubsection{Steroids}

Fifteen steroids (cholesterol, coprostanol, epicoprostanol, cholestanol, $\alpha$-cholestanol, campesterol, campestanol, stigmasterol, stigmastanol, $5 \beta$-stigmastanol, $5 \beta$-epistigmastanol, sitosterol, sitostanol, 24-ethylcoprostanol and 24-ethylepicoprostanol) were quantified in 9 bovine and 4 porcine manures and 6 WWTP effluents. These samples were frozen for 2 days at $-10{ }^{\circ} \mathrm{C}$ and freeze-dried for 3 days before analyses. Concentrations were determined as in Jardé et al. (2009). Steroid compounds were separated by liquid chromatography. After derivatization using N,O-bis(trimethylsilyl)trifuoroacetamide - trimethylchlorosilane (99/1, v/v), quantifications were performed on a Shimadzu QP2010+ gas chromatograph mass spectrometer. The chromatographic separation was performed on a SLBTM-5ms column (Supelco, $60 \mathrm{~m}, 0.25 \mathrm{~mm}, 0.25 \mu \mathrm{m}$ ) with the program: $70^{\circ} \mathrm{C}$ (held at $1 \mathrm{~min}$ ) to $130^{\circ} \mathrm{C}$ at $15^{\circ} \mathrm{C} / \mathrm{min}$, then $130^{\circ} \mathrm{C}$ to $300^{\circ} \mathrm{C}$ (held at $15 \mathrm{~min}$ ) at $3^{\circ} \mathrm{C} / \mathrm{min}$. Helium flow was maintained at 1 $\mathrm{mL} / \mathrm{min}$. Quantification of steroid compounds was performed by adding of ${ }^{2} \mathrm{H}_{6}$-cholestane as an internal standard.

\subsubsection{Human faecal chemical pollution markers}

Eight compounds (caffeine, diphenhydramine tri(2-chloroethyl)phosphate (TCEP), tri(dichloroisopropyl)phosphate (TDCP), triclosan, ethyl citrate, galaxolide and tonalide) were selected among the 35 compounds that had been shown to be useful as indicators of anthropogenic pollution in the study by Glassmeyer et al. (2005). Except caffeine, which was chosen because of its wide use as chemical tracer, all the other compounds were selected due to their $100 \%$ frequency in wastewater effluents and their potential to be detected using a simple multiresidue method. 
Water samples $(250 \mathrm{~mL}$ ) were vacuum filtered through a $1.2 \mu \mathrm{m}$ GF/C filter (Whatman) and extracted with Oasis $\mathrm{HLB}^{\circledR}$ cartridges $\left(500 \mathrm{mg}, 6 \mathrm{~cm}^{3}\right)$ as in Zaugg et al. (2002). Phenanthrene-d10 was used as surrogate standard.

Sample extracts (1 $\mathrm{mL}$ in ethyl acetate) were analysed using a GC/MS/MS system: Varian GC 3800 equipped with a Varian 8400 autosampler, and coupled to a Varian 4000 ion trap mass spectrometer operating in electron impact ionization mode at $70 \mathrm{eV}$. Separation was performed using a FactorFour VF-5 ms column.

The GC conditions were: splitless injection $\left(290{ }^{\circ} \mathrm{C}, 2 \mathrm{~min}, 2 \mu \mathrm{L}\right.$ injection volume, $1 \mathrm{~mL} / \mathrm{min}$ $\mathrm{He}$ ) and a temperature program of $60^{\circ} \mathrm{C}$ for $3 \mathrm{~min}, 20^{\circ} \mathrm{C} / \mathrm{min}$ to $200^{\circ} \mathrm{C}, 5 \mathrm{~min}$ isothermal, 10 ${ }^{\circ} \mathrm{C} / \mathrm{min}$ to $280{ }^{\circ} \mathrm{C}$ and $15{ }^{\circ} \mathrm{C} / \mathrm{min}$ to $320^{\circ} \mathrm{C}$. The ion trap was maintained at $200{ }^{\circ} \mathrm{C}$, the manifold at $80{ }^{\circ} \mathrm{C}$ and the line transfer at $260{ }^{\circ} \mathrm{C}$. The mass detection parameters were individually optimized for each analysis, as collision energy was required to produce the daughter ions.

The most intense peak(s) of daughter ions were used for quantification.

\subsubsection{F-specific RNA bacteriophages}

FRNAPH were enumerated following the ISO 10705 method (Anonymous 2001). FRNAPH genotyping was done on bacteriophage isolates by plaque hybridization with labelled oligonucleotide probes designed by Beekwilder et al. (1996). Faeces of humans, pigs, cows, sheep and birds $(n=125)$, and effluent samples ( $n=100$; WWTP effluent, porcine and bovine manure) were analysed to evaluate sensitivity and specificity of this method. However, as the plaque hybridization method is time-consuming, a new genotyping method was also carried out based on real-time RT-PCR (Reverse Transcriptase-PCR) with a One-Step RT-PCR kit (QuantiTech Probe RT-PCR, Qiagen; Ogorzaly et al., 2009) using primers and probes described in Ogorzaly and Gantzer (2006, Table 1).

A comparison was made between the two methods on 60 representative or environmental bacteriophage isolates.

FRNAPH concentrations were expressed in plaque-forming units (PFU) per g faeces or per $100 \mathrm{~mL}$ water. The quantification limit is 1 PFU per $\mathrm{g}$ faeces and 10 PFU par $100 \mathrm{~mL}$ water. Only results with at least 20 successfully-genotyped plaques were considered as valid FRNAPH source tracking results. Indeed, due to the statistical variation of results from FRNAPH tests, those of $<20$ PFU were considered to be inconclusive (Stapleton et al., 2007). Results are expressed in percentage (\%) human (II or III) or animal (I or IV) genogroups/total FRNAPH isolated.

Table 1. Primer and probe sequences for real-time PCR for detection of bacterial markers and of four F-specific RNA phage genogroups 


\begin{tabular}{|c|c|c|c|c|c|c|}
\hline $\begin{array}{l}\text { Primers and } \\
\text { probe }\end{array}$ & $\begin{array}{l}\text { Sequences } \\
\quad\left(5^{\prime} \rightarrow 3^{\prime}\right)\end{array}$ & $\begin{array}{c}\text { Amplico } \\
\text { n size } \\
\text { (bp) }\end{array}$ & $\begin{array}{c}\text { Annealing } \\
\text { temperature } \\
\left({ }^{\circ} \mathrm{C}\right)\end{array}$ & $\begin{array}{l}\text { Final } \\
\text { concent } \\
\text { ration } \\
\text { (nmol) }\end{array}$ & Target & References \\
\hline \multicolumn{7}{|l|}{ AllBac } \\
\hline$\overline{\text { AllBac}} 296 \mathrm{~F}$ & GAGAGGAAGGTCCCCCAC & 106 & 60 & 200 & All- & Layton \\
\hline AllBac467R & CGCTACTTGGCTGGTTCAG & & & 200 & Bacteroidales & et al., (2006) \\
\hline AllBac375Bhqr & $\begin{array}{l}\text { (FAM)CCATTGACCAATATTCCTCACTGCTGCT } \\
\text { (BHQ-1) }\end{array}$ & & & 100 & général & \\
\hline \multicolumn{7}{|c|}{ 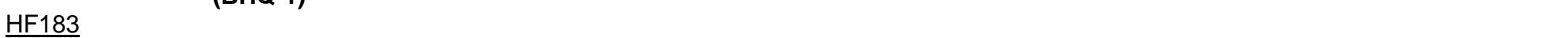 } \\
\hline$\overline{\mathrm{HF} 183 \mathrm{f}}$ & ATCATGAGTTCACATGTCCG & 83 & 60 & 200 & Human & Seurinck \\
\hline HF183r & TACCCCGCCTACTATCTAATG & & & 200 & $\begin{array}{l}\text { specifc } \\
\text { Bacteroidales }\end{array}$ & et al., (2005) \\
\hline \multicolumn{7}{|l|}{ Rum-2-Bac } \\
\hline BacB2-590F & ACAGCCCGCGATTGATACTGGTAA & 99 & 60 & 200 & Ruminant- & Mieszkin et al., \\
\hline Bac708Rm & CAATCGGAGTTCTTCGTGAT & & & 200 & specific & (2010) \\
\hline BacB2-626P & $\begin{array}{l}\text { (FAM)ATGAGGTGGATGGAATTCGTGGTGT(BHQ } \\
\text {-1) }\end{array}$ & & & 200 & Bacteroidales & \\
\hline \multicolumn{7}{|l|}{ Pig-1-Bac } \\
\hline 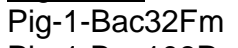 & AACGCTAGCTACAGGCTTAAC & 129 & 60 & 200 & Pig-specific & Mieszkin \\
\hline Pig-1-Bac108R & CGGGCTATTCCTGACTATGGG & & & 200 & Bacteroidales & et al., (2009) \\
\hline Pig-1-Bac44P & $\begin{array}{l}\text { (FAM)ATCGAAGCTTGCTTTGATAGATGGCG(BH } \\
\text { Q-1) }\end{array}$ & & & 200 & & \\
\hline \multicolumn{7}{|l|}{ Pig-2-Bac } \\
\hline$\overline{\text { Pig-2-Bac } 41 F}$ & GCATGAATTTAGCTTGCTAAATTTGAT & 116 & 60 & 300 & Pig-specific & Mieszkin \\
\hline Pig-2- & ACCTCATACGGTATTAATCCGC & & & 300 & Bacteroidales & et al., (2009) \\
\hline Bac163Rm & (VIC)TCCACGGGATAGCC(NFQ-MGB) & & & 200 & & \\
\hline \multicolumn{7}{|l|}{$\begin{array}{l}\text { Pig- } \\
\text { 2Bac113MGB }\end{array}$} \\
\hline \multirow[t]{2}{*}{ L. amylovorus } & TTCTGCCTTTTTGGGATCAA & 175 & 60 & 200 & $L$. & Konstantinov et \\
\hline & CCTTGTTTATTCAAGTGGGTGA & & & 200 & amylovorus & al., (2006) \\
\hline Bifid. & & & & & Human- & This study \\
\hline$\overline{\text { adolescentis }}$ & GGGTGGTAATGCCGGATG & 325 & 60 & 300 & specific & \\
\hline W257F & GGTGCTTATTCGAAAGGTACACTCA & & & 300 & Bifidobacteria & \\
\hline W255R & (FAM)ATGTCCTTCTGGGAAAGATTCATCGGTAT & & & 100 & Phylotype & \\
\hline W256P & G (TAMRA) & & & & & \\
\hline \multicolumn{7}{|l|}{ FRNAPH I } \\
\hline GIF & TCGATGGTCCATACCTTAGATGC & 176 & 60 & 400 & Animal & \\
\hline GIR & ACCCCGTTAGCGAAGTTGCT & & & 400 & genogroups & \\
\hline GIP & (FAM)CTCGTCGACAATGG(MGBNFQ) & & & 150 & & \\
\hline \multicolumn{7}{|l|}{ FRNAPH II } \\
\hline GIIF & TGCAAACCTAACTCGGAATGG & 72 & 60 & 400 & Human & \\
\hline GIIR & AGGAGAGAACGCAGGCCTCTA & & & 400 & genogroups & \\
\hline GIIP & (FAM)TCССТСТАTTTCСТC (MGBNFQ) & & & 150 & & Ogorzaly \\
\hline FRNAPH III & & & & & & Gantzer, (2006) \\
\hline GIIIF & CCGCGTGGGGTAAATCC & 115 & 60 & 400 & Human & \\
\hline GIIIR & TTCTTACGATTGCGAGAAGGCT & & & 400 & genogroups & \\
\hline GIIIP & (FAM) AAGCGGGTGCAGTT(MGBNFQ) & & & 150 & & \\
\hline \multicolumn{7}{|l|}{ FRNAPH IV } \\
\hline GIVF & GCTACTAGCCTTCGTCGCAAGA & 62 & 60 & 400 & Animal & \\
\hline GIVR & GAAGGCACTGTCCTGAATCCA & & & 400 & genogroups & \\
\hline GIVP & (FAM)AGGTCGGTACAAAGTG (MGBNFQ) & & & 150 & & \\
\hline
\end{tabular}


Sample collection and DNA extraction

Individual human faecal samples were obtained from 10 healthy adult and child volunteers from Brittany (France). Individual animal faecal samples were collected immediately after excretion from apparently healthy animals (14 pigs, 14 cows, 10 sheep and 10 horses).

Porcine faecal samples were collected from adult sows and boars, young pigs, and piglets mainly housed in stalls on farms in Brittany. Cow faecal samples were collected from animals kept on pasture or housed in stalls, and included samples from adults and heifers on beef and dairy farms in Brittany and Normandy. Samples from sheep were collected from one farm in Brittany and from salt meadows on two farms in Normandy. Samples from horses were collected from stud farms in Brittany and Pays de la Loire. Poultry droppings $(n=4)$ were collected from a henhouse in Brittany. Wild bird faeces $(n=15)$ were collected on two beaches in Brittany.

Eight WWTP water samples were collected at the outlets of eight independent municipal WWTP (not connected to slaughterhouses) in Pays de la Loire.

Six porcine manure samples were collected from six separate farms in Brittany.

For faeces samples, DNA was extracted from $250 \mathrm{mg}$ wet weight of samples using the Fast DNA Spin Kit for Soil (MP Biomedical, Illkirsh, France) according to Dick et al. (2005). Porcine manure and WWTP samples were centrifuged at $9000 \mathrm{~g}$ for $15 \mathrm{~min}$ and DNA extracted from $200 \mathrm{mg}$ of the pellet using the DNA stool mini kit.

\section{Real-time PCR}

A real-time PCR system was designed to specifically amplify the phylotype SFA 41 related to Bifid. adolescentis identified in Wéry et al. (2010) (Table 1). The forward Bifidobacterium primer (W257F) was previously published by Germond et al. (2002). The probe (W256P) and reverse primer (W255R) were designed using ARB, BLASTN, Primer BLAST (NCBI, http://blast.ncbi.nlm.nih.gov/Blast.cgi) and Primer Express ${ }^{\circledR}$ (Applied Biosystems).

Real-time PCR were done in $25 \mu \mathrm{L}$, using 96-well optical reaction plates. PCR of Bifid. adolescentis used $12.5 \mu \mathrm{L} 2 \mathrm{X}$ qPCR Mastermix Plus for probes (Eurogentec, France), $5 \mu \mathrm{L}$ diluted DNA, primers (300 nM) and TaqMan probe (100 nM). Amplifications were run on ABI Prism 7000 SDS equipment (Applied Biosystems). The PCR program was: $10 \mathrm{~min}$ at $95^{\circ} \mathrm{C}$, then 40 cycles of $15 \mathrm{~s}$ at $95^{\circ} \mathrm{C}$ and 1 min at $60^{\circ} \mathrm{C}$.

The presence/absence of PCR inhibitors was verified using an Internal Positive Control (IPC) (AppliedBiosystem, France). Samples were diluted if inhibitors were present. DNA samples were tested with the IPC at no-dilution (ND), 1/10 and 1/100 dilution. The DNA samples without inhibition were used for the PCR reactions. Negative controls (no template DNA) were performed for each run.

Host-specific PCR assays were tested on faeces and effluent samples. Sensitivity and specificity were calculated according to Gawler et al. (2007).

All samples were tested in triplicate. Plasmid DNA containing partial 16S rRNA gene sequence insert was used as a standard at 10-fold dilutions ranging from $5 \times 10^{7}$ to $5 \times 10^{0}$ gene copies per real-time PCR, with a quantification limit of 5 target copies per reaction.

Consequently, the lower limit for quantification of Bifid. adolescentis marker was $3 \times 10^{4}$ copies per $\mathrm{g}$ in faeces and $1 \times 10^{3}$ copies per $100 \mathrm{ml}$ water.

\subsection{In situ application of host-specific microbial and chemical markers}

\subsubsection{Runoff, WWTP effluent and river water samples}

Independent samples of field runoff were collected after six rainfall simulations on an experimental agricultural plot (Brittany, France) spread with either bovine (samples B1 to B3) or porcine manure (samples P1 to P3).

Four WWTP effluents (WW1 to WW4) from Pays de la Loire (France) were sampled after the secondary sedimentation tank. 
Three samples were collected from a river (Brittany, France) flowing through an agricultural area associated with intensive cattle grazing (C1 to C3).

Twenty water samples (R1 to R20) were collected from two rivers in Pays de la Loire, both flowing though agricultural areas and receiving WWTP discharges.

All water samples were collected in plastic bottles and transferred at $4{ }^{\circ} \mathrm{C}$ to each laboratory. Samples for chemical analyses were stored at $-20^{\circ} \mathrm{C}$, whereas samples for microbial analysis were analysed within 24 hours of collection.

E. coli was enumerated using TBX medium (Oxoid, France) and concentrations were expressed in colony-forming units (CFU) per $100 \mathrm{~mL}$ water. Some blue colonies were transferred into Peptone Water (Oxoid, France) and incubated for $24 \mathrm{~h}$ at $44{ }^{\circ} \mathrm{C}$ for the confirmation of $E$. coli. After incubation, $0.5 \mathrm{~mL}$ Kovac's Indole reagent (Labogros, France) was added. The detection limit is $1 \mathrm{CFU}$ per $100 \mathrm{~mL}$ water.

The Table 2 present all MST markers and general indicators tested in environmental waters. 
Table 2. Description of 17 microbial and chemical parameters tested during the in situ application of MST markers

\begin{tabular}{|c|c|c|c|c|c|}
\hline $\begin{array}{ll}\text { MST Markers I general indicators } & \begin{array}{l}\text { Ab } \\
\mathrm{S}\end{array} \\
\end{array}$ & bbreviation & Type of marker(target) & $\begin{array}{l}\text { Origin } \\
\text { pollution }\end{array}$ & Methods & References \\
\hline $\begin{array}{l}\text { Host-specific Bacteroidales markers } \\
\text { - HF183 } \\
\text { - Rum-2-Bac } \\
\text { - Pig-1-Bac } \\
\text { - Pig-2-Bac }\end{array}$ & $\begin{array}{l}\text { HF183 } \\
\text { Rum-2 } \\
\text { Pig-1 } \\
\text { Pig-2 }\end{array}$ & $\begin{array}{l}\text { Microbial } \\
\text { (anaerobic bacteria - } \\
\text { 16S rRNA gene) }\end{array}$ & $\begin{array}{l}\text { Human } \\
\text { Ruminant } \\
\text { Porcine } \\
\text { Porcine }\end{array}$ & Real-time PCR & $\begin{array}{ll}\text { Mieszkin } & \text { et } \\
\text { al., (2009) } & \\
\text { Mieszkin } & \text { et } \\
\text { al., (2010) } & \end{array}$ \\
\hline $\begin{array}{l}\text { Pig-specific bacterial marker } \\
\text { - Lactobacillus amylovorus }\end{array}$ & L. amy & $\begin{array}{l}\text { Microbial } \\
\text { (anaerobic bacteria - } \\
\text { genomic RDA fragment) }\end{array}$ & Porcine & Real-time PCR & $\begin{array}{l}\text { Marti et al., } \\
(2010)\end{array}$ \\
\hline $\begin{array}{l}\text { F-specific RNA bacteriophages } \\
\text { - FRNAPH I } \\
\text { - FRNAPH II } \\
\text { - FRNAPH III } \\
\text { - FRNAPH IV }\end{array}$ & $\begin{array}{l}\text { FR I } \\
\text { FR II } \\
\text { FR III } \\
\text { FR IV }\end{array}$ & $\begin{array}{l}\text { Microbial } \\
\text { (virus of enteric bacteria) }\end{array}$ & $\begin{array}{l}\text { Animal } \\
\text { Human } \\
\text { Human } \\
\text { Animal }\end{array}$ & $\begin{array}{l}\text { Culture/ genotyping } \\
\text { by real -time RT-PCR }\end{array}$ & $\begin{array}{l}\text { This study } \\
\text { Ogorzaly et } \\
\text { al., (2009) }\end{array}$ \\
\hline $\begin{array}{l}\text { Steroids } \\
\text { - R1: coprostanol/24-ethylcoprostanol } \\
\\
\text { - R2: sitostanol/coprostanol } \\
\text { Escherichia coli } \\
\text { All-Bacteroidales } \\
\text { F-specific RNA bacteriophages } \\
\text { Total Steroids }\end{array}$ & $\begin{array}{l}\quad \text { R2 } \\
\text { E. coli } \\
\text { AllBac } \\
\text { FRNAPH } \\
\text { T. Steroids }\end{array}$ & $\begin{array}{l}\text { Microbial } \\
\text { Microbial } \\
\text { Microbial } \\
\text { Chemical }\end{array}$ & $\begin{array}{l}\text { Human/porcine- } \\
\text { bovine } \\
\text { Bovine/porcine- } \\
\text { human }\end{array}$ & $\begin{array}{lr}\begin{array}{l}\text { Liquid } \\
\text { extraction }\end{array} & \begin{array}{r}\text { solid } \\
\text { and } \\
\text { capillary }\end{array} \\
\text { GColus } & \text { column } \\
\text { Culture } & \\
\begin{array}{l}\text { Real-time } \\
\text { Culture }\end{array} & \\
\text { Liquid } & \\
\text { extraction } & \text { solid } \\
\end{array}$ & $\begin{array}{l}\text { This study } \\
\text { Jardé et al., } \\
\text { (2009) }\end{array}$ \\
\hline
\end{tabular}




\subsubsection{Chemical markers}

For steroid compounds, one litre of each water sample was frozen for 2 days at $-10{ }^{\circ} \mathrm{C}$ after filtration at $0.45 \mu \mathrm{m}$, and freeze-dried for 3 days before analyses. Then, 0.01 to $0.2 \mathrm{~g}$ of freeze-dried samples were extracted and analysed as described in section 2.1.1

The other chemical markers were quantified on $250 \mathrm{~mL}$-water samples as described in section 2.1.2.

\subsubsection{FRNAPH}

FRNAPH were enumerated following the ISO method, directly or after concentration by ultrafiltration with a Centricon Plus-70 (Millipore) for the less contaminated water samples. Bacteriophage isolates were then genotyped by real-time RT-PCR, with the One-Step RT-PCR kit, as in Ogorzaly et al. (2009).

\subsubsection{Bacterial markers}

For river water and WWTP effluent samples, $25-200 \mathrm{~mL}$ water were filtered on $0.22 \mu \mathrm{m}$ polycarbonate membrane (Nuclepore) for Bacteroidales and L. amylovorus marker analyses, and on $0.22 \mu \mathrm{m}$ polyethersulfone filter (Supor 200; Pall Corporation, Ann Arbor, MI) for Bifid. adolescentis. Filters were stored at $-20^{\circ} \mathrm{C}$. DNA was extracted with a modified DNA mini kit (Qiagen) protocol as in Mieszkin et al. (2009) or by using the DNA stool mini kit (Qiagen) as in Marti et al. (2010). Results from these two protocols were similar (data not shown).

For runoff, approximately $50 \mathrm{~mL}$ water were centrifuged at $9000 \mathrm{~g}$ for $15 \mathrm{~min}$, and $250 \mathrm{mg}$ of the pellet were transferred into microtubes and stored at $-20{ }^{\circ} \mathrm{C}$. DNA was extracted using the Fast DNA Spin Kit for Soil (MP Biomedicals, Illkirsh, France), according to Dick et al. (2005).

Previously described primers-and-probe and primer sets for all-Bacteroidales (AllBac), HF183, Pig-1-Bac, Pig-2-Bac, Rum-2-Bac and L. amylovorus markers (Seurinck et al., 2005; Layton et al., 2006; Mieszkin et al., 2009, 2010; Marti et al. 2010; Table 1) were used to amplify total Bacteroidales; human-, pig-, and ruminant-specific Bacteroidales and 16S rRNA genes; and the L. amylovorus RDA gene. PCR amplifications of general and host-specific Bacteroidales markers, L. amylovorus and Bifid. adolescentis were performed as in Mieszkin et al. (2009, 2010), Marti et al. (2010) and section 2.1.4.

A standard curve was generated using serial 10 -fold dilutions of a plasmid preparation containing the target sequence for Bacteroidales and Bifid. adolescentis markers or bacterial genomic DNA extracted from a pure-strain culture for the L. amylovorus marker. The presence/absence of PCR inhibitors was verified using an Internal Positive Control (IPC) (AppliedBiosystem, France). All samples were tested in triplicate.

The lower limit of quantification of the all-Bacteroidales, host-specific Bacteroidales and Bifid. adolescentis markers was $1 \times 10^{3}$ 16S RNA gene copies per $100 \mathrm{ml}$ water, and the lower limit of quantification of $L$. amylovorus marker was $1 \times 10^{3}$ cells per $100 \mathrm{ml}$.

\subsection{Statistical analysis}

To take into account values below the quantification limit, quantitative data were transformed into categorical data $(0=$ not quantified; $1-3=$ relative to concentrations or ratios). Relations between samples and presence of each marker were studied by Multiple Correspondence Analysis (MCA) using FactoMineR and Hierarchical Classification on Principle Components (HCPC) by Ward's method. Euclidean distance was calculated between individuals. All calculations were performed and graphics drawn using $\mathrm{R}$ version v.2.9.2. 


\section{Results}

\subsection{Development and testing of methods for the selection of chemical and microbial markers on faecal samples}

\subsubsection{Steroids}

The 19 samples of animal faeces and WWTP effluents were characterized by the presence of $\mathrm{C}_{27}, \mathrm{C}_{28}$ and $\mathrm{C}_{29}$ sterol and stanol compounds. The major compounds in the samples of bovine manure were the $\mathrm{C}_{28}$ and $\mathrm{C}_{29}$ steroids, which represented between $65 \%$ and $75 \%$ of the steroids quantified. Among $\mathrm{C}_{28}$ and $\mathrm{C}_{29}$ steroids, sitostanol (12 to $14 \%$ ) and 24ethylepicoprostanol (14\% to $18 \%$ ) were the main compounds present in bovine manure. In porcine manure samples, the distribution of steroids was roughly the same in $\mathrm{C}_{27}$ compounds (45 to $53 \%$ ) as in $\mathrm{C}_{28}$ and $\mathrm{C}_{29}$ compounds (46 to $55 \%$ ). The major compounds were coprostanol (20 to $27 \%$ ), 24-ethylcoprostanol (17 to $19 \%$ ), and sitosterol (7 to $8 \%$ ). These results are consistent with the previous studies of Leeming et al. (1996) and Jardé et al. (2007). In WWTP effluent samples, $C_{27}$ steroids, which are the main compounds, represent between 64 and $73 \%$ of the quantified steroids. They were represented essentially by coprostanol (30 to $41 \%$ ), cholesterol (21 to $29 \%$ ), 24-ethylcoprostanol (10 to $16 \%$ ) and sitostrol (6 to $12 \%)$. According to the distribution of the steroid in the animal manure and WWTP effluent samples, two ratios were calculated to differentiate the samples:

- R1 or (cop/cop+24-ethylcop) $\times 100$, i.e. coprostanol concentration/sum of coprostanol and 24-ethylcoprostanol, expressed as a percentage.

- R2 or sitostanol/coprostanol, i.e. sitostanol concentration/coprostanol concentration. This ratio illustrates the proportion of stanol produced by the degradation of cholesterol over the proportion of stanol derived from phytosterol.

Table 3 displays the mean values of $\mathrm{R} 1$ and $\mathrm{R} 2$ ratios for bovine and porcine manures and WWTP effluents.

R1 showed different discrete ranges and means for bovine, porcine and human (WWTP) sources. R1 ratio therefore distinguishes animal manures (R1<60\%) from WWTP effluents $(\mathrm{R} 1>60 \%)$. R2 ratio provides complementary information for sample discrimination. R2 ratios were $>1$ for bovine manures, and $<1$ for porcine manures and WWTP effluents.

Table 3. Steroid ratios for animal manures and WWTP effluents

\begin{tabular}{lccc}
\hline Origin & $\begin{array}{l}\text { No. } \\
\text { samples }\end{array}$ & $\begin{array}{c}\text { (cop/(24ethyl+cop) }) \times \mathbf{1 0 0}^{\mathrm{a}} \\
(\mathbf{R} 1, \text { in } \%)\end{array}$ & $\begin{array}{c}\text { sitostanol/coprostanol } \\
\text { (R2) }\end{array}$ \\
\hline & & Mean \pm S.E & Mean \pm S.E \\
Bovine manure & 9 & $41 \pm 1$ & $2.8 \pm 0.1$ \\
Porcine manure & 4 & $57 \pm 2$ & $0.3 \pm 0.1$ \\
WWTP effluent & 6 & $71 \pm 2$ & $0.1 \pm 0.01$ \\
\hline
\end{tabular}

acoprostanol/coprostanol+24-ethylcoprostanol; ${ }^{0}$ standard error

\subsubsection{Human faecal chemical pollution markers}

The instrumental limits of quantification were determined below $10 \mu \mathrm{g} / \mathrm{L}$ according to the AFNOR XP T90-210 standard method, leading us to set an analytical quantification limit of $0.04 \mu \mathrm{g} / \mathrm{L}$ for all compounds in water.

The procedure was validated in tap and surface water according to the SANCO/825/00 rev.7 standard. The majority of compounds gave $70-110 \%$ acceptable recoveries with $<20 \%$ RSD (Relative Standard Deviation); concentrations ranged from $0.04 \mu \mathrm{g} / \mathrm{L}$ to $0.4 \mu \mathrm{g} / \mathrm{L}$. Matrix effects were observed for ethyl citrate and TDCP, giving unacceptable recoveries, and 
diphenhydramine was not recovered at all. These three molecules were excluded from further analyses.

Target compound concentrations were then measured in triplicate in five WWTP effluents from two sampling campaigns to verify that the selected molecules were present in the effluents. Extraction was satisfactory for all samples in the first campaign, since recoveries of the surrogate standard (phenanthrene-d10) were 101$111 \%$, and the results are reported in table 4. Apart from tonalide, the five molecules were detected in all samples at concentrations above the quantification limit. The value obtained for tonalide is, however, acceptable (individual $\mathrm{LQ}=0.02 \mu \mathrm{g} / \mathrm{L}$ ). Mean levels varied between $0.03 \mu \mathrm{g} / \mathrm{L}$ (tonalide) and $0.51 \mu \mathrm{g} / \mathrm{L}$ (TCEP) and concentrations of the individual compounds were similar among WWTP, as indicated by the RSD. In the second sampling campaign, recovery rate of phenanthrene-d10 was good for WWT2 (96 \%) but much lower (52 to $62 \%$ ) for the other samples. A correction factor, taking into account the recovery rate of phenanthrene-d10, was therefore applied to results from the 4 other WWTP. Some levels (in italics in Table 4) were out of the range of the calibration curve; the values for this second campaign are therefore estimates. Despite these approximations, it is clear that the selected molecules are present in WWTP effluents and are good candidates for tracing human faecal pollution.

Table 4. Concentrations ( $\mu \mathrm{g} / \mathrm{L})$ of human faecal chemical pollution markers in WWTP effluents during the two sampling campaigns

\begin{tabular}{|c|c|c|c|c|c|}
\hline $\begin{array}{l}\text { WWTP } \\
\text { Effluent }\end{array}$ & $\begin{array}{c}\text { Benzophenon } \\
\text { e }\end{array}$ & TCEP & $\begin{array}{l}\text { Galaxolid } \\
\text { e }\end{array}$ & Tonalide & Caffeine \\
\hline & $1^{\text {st }}-2^{\text {nda }}$ & $1^{\text {st }}-2^{\text {nd }}$ & $1^{\text {st }}-2^{\text {nd }}$ & $1^{\text {st }}-2^{\text {nd }}$ & $1^{\text {st }}-2^{\text {nd }}$ \\
\hline WWTP1 & $0.2-1.7$ & $0.85-0.6$ & $0.4-12.6$ & $0.07-0.6$ & $0.5-30.1$ \\
\hline WWTP2 & $0.3-0.3$ & $0.45-0.6$ & $0.5-1.9$ & $\begin{array}{l}0.03- \\
0.07\end{array}$ & $0.4-0.2$ \\
\hline WWTP3 & $0.15-1.2$ & $0.35-0.2$ & $0.4-3.6$ & 0.03- 0.4 & $0.2-26.9$ \\
\hline WWTP4 & $0.2-3.2$ & $0.6-0.2$ & $0.4-8.6$ & $0.02-0.4$ & $0.15-21.5$ \\
\hline WWTP5 & $0.3-1.9$ & $0.35-0.2$ & $0.6-11.2$ & $0.03-0.4$ & $0.2-32.1$ \\
\hline Mean & $0.2-1.65$ & $0.5-0.3$ & $0.5-7.6$ & $0.03-0.4$ & $0.3-22.2$ \\
\hline RSD (\%) ${ }^{b}$ & $29-54.7$ & $41-59.5$ & $20-62.1$ & $63-34.5$ & $53-58.3$ \\
\hline
\end{tabular}

${ }^{a}$ First and second sampling campaigns; ${ }^{1}$ Related Standard Deviation expressed in percentage Data in bold: out of calibration curve range

\subsection{FRNAPH}

Among the 121 animal faeces analysed, FRNAPH were only detected in $26.4 \%$ of the faeces: 2 bovine, 18 porcine, 1 ovine and 11 avian faeces samples (at 1 to $5.5 \times 10^{5}$ PFU per $\mathrm{g}$ of faeces) (Table 5). FRNAPH genotypes identified were mainly animal ones i.e. FRNAPH I and, to a lesser extent, FRNAPH IV. Human-specific FRNAPH II and FRNAPH III were also detected in avian and porcine faecal samples, respectively. Nevertheless, FRNAPH were more frequently detected in WWTP effluent samples $(94.3 \%)$ and porcine manure (40 \%) than in faeces samples. FRNAPH I and IV represented $81.6 \%$ of FRNAPH isolated in porcine manure samples whereas FRNAPH II and III represented $75.3 \%$ of those isolated in WWTP samples. FRNAPH I and IV appeared particularly inefficient for tracing bovine pollution, as they were detected in less than $7 \%$ of bovine (faeces and manure) samples.

To improve genotyping, plaque hybridization and real-time RT-PCR were compared in a total of 60 FRNAPH strains for the four genogroups. Results were $97 \%$ concordant (only two 
FRNAPH isolates differed), showing real-time RT-PCR genotyping to be equivalent to plaque hybridization.

Table 5 Percentages of the four genogroups of FRNAPH in human and animal faeces and effluents

\begin{tabular}{|c|c|c|c|c|c|c|c|c|c|}
\hline Samples & $\begin{array}{l}\text { No. } \\
\text { sample } \\
\text { s }\end{array}$ & $\begin{array}{l}\text { No. } \\
\text { positiv } \\
\text { e } \\
\text { sample } \\
\text { s }\end{array}$ & $\begin{array}{l}\text { Total } \\
\text { no. of } \\
\text { isolate } \\
\mathrm{s}\end{array}$ & $\begin{array}{l}\text { \% of } \\
\text { positive } \\
\text { sample } \\
\text { s }\end{array}$ & $\begin{array}{l}\text { FRNAPH } \\
\text { I }^{\text {a }}(\%)\end{array}$ & $\begin{array}{l}\text { FRNAPH } \\
\text { II }^{\mathrm{a}}(\%)\end{array}$ & $\begin{array}{l}\text { FRNAPH } \\
\text { III }^{\mathrm{a}}(\%)\end{array}$ & $\begin{array}{l}\text { FRNAPH } \\
\text { IV }^{\mathrm{a}}(\%)\end{array}$ & $\begin{array}{l}\text { Genotypes not } \\
\text { identified (\%) }\end{array}$ \\
\hline Human faeces & 4 & 0 & 0 & 0 & & & & & \\
\hline $\begin{array}{l}\text { Porcine } \\
\text { faeces }\end{array}$ & 48 & 18 & 425 & 37.5 & $\overline{7} 1.5$ & $\overline{0}$ & $\overline{0}$ & $\overline{2} 8.5$ & $\overline{0}$ \\
\hline Bovine faeces & 32 & 2 & 24 & 6.2 & 52.1 & 0 & 0 & 0 & 47.9 \\
\hline Ovine faeces & 12 & 1 & 24 & 8.3 & 100 & 0 & 0 & 0 & 0 \\
\hline Avian faeces & 29 & 11 & 259 & 38 & 72.6 & 10.4 & 0 & 8.2 & 8.8 \\
\hline $\begin{array}{l}\text { WWTP } \\
\text { effluent }\end{array}$ & 35 & 33 & 810 & 94.3 & 6.9 & 57.9 & 17.4 & 1.9 & 15.9 \\
\hline $\begin{array}{l}\text { Porcine } \\
\text { manure }\end{array}$ & 35 & 14 & 364 & 40 & 65.9 & 0 & 13.7 & 15.7 & 4.7 \\
\hline $\begin{array}{l}\text { Bovine } \\
\text { manure }\end{array}$ & 30 & 2 & 26 & 6.7 & 12 & 30.7 & 0 & 0 & 57.7 \\
\hline
\end{tabular}

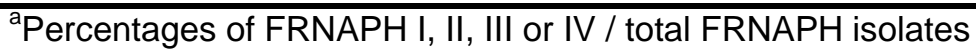

\subsubsection{B. adolescentis marker}

A new real-time PCR system was developed to quantify the phylotype related to $B$. adolescentis, previously identified as a potential human marker (Wéry et al., 2010). Phylotype concentrations in different sample types are given in Table 6 . The marker was found in all WWTP effluents and in 9/10 human faeces tested, implying $92 \%$ sensitivity. Concentrations in human faeces ranged from $5 \times 10^{5}$ to $1 \times 10^{9}$ gene copies $/ \mathrm{g}$. As this marker was not found in porcine, avian, equine or ovine faeces but was present in two bovine faeces and two avian faeces, specificity was $94.5 \%$. Although this new marker was not strictly specific to humans, its presence and concentrations were lower in bovine and avian faeces than in human faeces, and it was not recovered in porcine faeces or manure. It therefore represents an interesting marker for tracing human pollution, but only when combined with other markers.

Table 6. Specificity of the phylotype 'SFA41' related to Bifidobacterium adolescentis

\begin{tabular}{llll}
\hline Origin & No. & No. positive & Concentrations \\
& samples & samples & $\min -\max \log _{10}$ copies per $\mathbf{g}$
\end{tabular}

\begin{tabular}{|c|c|c|c|}
\hline Human faeces & 10 & 9 & $5 \times 10^{5}-1 \times 10^{9}$ \\
\hline Porcine faeces & 14 & 0 & \\
\hline Bovine faeces & 14 & 2 & $4 \times 10^{5}-1.3 \times 10^{6}$ \\
\hline Ovine faeces & 10 & 0 & \\
\hline Equine faeces & 10 & 0 & \\
\hline Avian faeces & 19 & 2 & $6.3 \times 10^{4}-7.9 \times 10^{6}$ \\
\hline WWTP effluent $^{a}$ & 8 & 8 & $1 \times 10^{4}-7.9 \times 10^{6}$ \\
\hline Porcine manure & 6 & 0 & \\
\hline
\end{tabular}




\subsection{In situ application of host-specific microbial and chemical markers}

Table 7 gives average concentrations for faecal indicators, MST markers and ratios of steroids in 33 water samples including WWTP effluent, runoff and river samples. FRNAPH, and total Bacteroidales were significantly correlated $(p<0.001)$ with $E$. coli levels.

Highly contaminated samples (WWTP effluent and runoff waters, with $E$. coli concentrations ranging between $6.6 \times 10^{3}$ and $1.1 \times 10^{6} \mathrm{CFU} / 100 \mathrm{~mL}$ ), could be differentiated with most of the human and animal MST markers. None of the 5 chemical markers of human pollution selected in the first phase of the study (i.e. caffeine, benzophenone, TCEP, tonalide and galaxolide) were detected in runoff waters impacted by livestock manures. However, tonalide was only detected in raw WWTP effluents and galaxolide was never detected in any of the rivers analysed (data not shown). The steroid ratios (R1 (cop/cop+24-ethylcop) $\times 100)$ and R2 (sistostanol/ coprostanol) clearly differed between waters contaminated by human and animal pollution. Microbial markers Rum-2-Bac, Pig-2-Bac and L. amylovorus were only detected in water impacted by the respective manures. The human Bacteroidales marker HF183 and Bifid. adolescentis were quantified in all the WWTP effluent samples, although HF183 appeared more discriminating since Bifid. adolescentis was also quantified in $1 / 3$ of the bovine-contaminated runoff samples. FRNAPH II and III were always present in variable proportions in urban sewage, but were also detected in bovine-impacted runoff waters. Moreover, animal FRNAPH I were not found only in animal effluents but also in 2/4 WWTP effluents.

In the 23 river water samples (C1-C3 and R1-R20), the concentration of E. coli ranged between $3.2 \times 10^{1}$ and $1.9 \times 10^{4} \mathrm{CFU} / 100 \mathrm{~mL}$. The number of $E$. coli was less or equal to $5 \times 10^{2} \mathrm{CFU} / 100 \mathrm{~mL}$ in 9 water samples. In 11 other water samples, the level of $E$. coli exceeded the limit value of the inland water guidelines of the European Directive on the management of bathing water quality.

The origin of pollution in the river flowing through cattle pasture (samples C1 to C3) was clearly identified by the R1 and R2 ratios, Rum-2-Bac and by the absence of human-specific Bacteroidales and the three human chemical faecal markers. Bifid. adolescentis was, however, quantified in $2 / 3$ of the water samples. In the 11 river water samples with highest $E$. coli concentrations, our results indicated mixed bovine and human pollution. Faecal pollution sources in the other 9 river water samples with low levels of $E$. coli $\left(\leq 5 \times 10^{2} \mathrm{CFU} / 100 \mathrm{~mL}\right)$ (i.e. samples R12 to R20) were more difficult to identify. Indeed, apart from caffeine and steroid ratios, the marker levels were below the limits of quantification in 7 of the 9 samples.

Analysis of the data obtained with the MCA gave the dendrogram shown in figure 1, which allows us to separate the water samples into six clusters characterized according to their significant modalities $(p<0.05)$. Three clusters were associated with one specific pollution source: clusters I, III and VI contained water samples contaminated by only porcine, bovine or human pollution, respectively. 


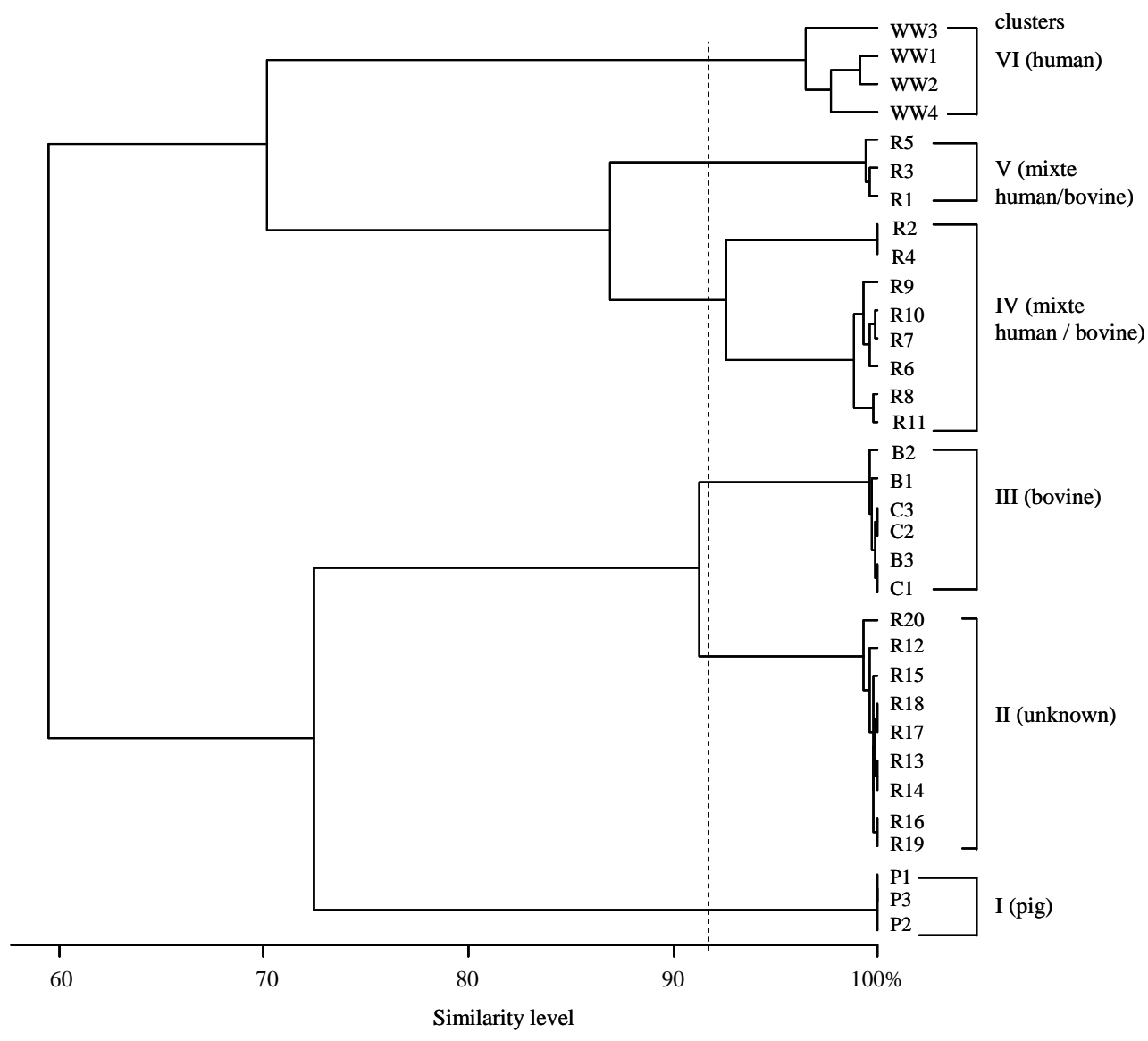

Figure 1. Dendrogram showing clustered water samples contaminated by waste water (WW1 to WW4), bovine manure or bovine pasture (B1 to B3 and C1 to C3), porcine manure (P1 to P3) and by undetermined pollution (R1 to R20)

The three other clusters corresponded to water samples from rivers where we had no specific knowledge about pollution origin, although human and bovine pollution was suspected. No human or animal markers were quantified in cluster II, and caffeine concentration was $<0.16 \mu \mathrm{g} / \mathrm{L}$. Cluster IV was characterized by intermediate concentrations of human markers $\left(0.17<\right.$ caffeine $<0.29 \mu \mathrm{g} / \mathrm{L} ; 10^{3}<$ Bifid. adolescentis $<10^{5}$ copies $/ 100$ $\mathrm{mL} ; 10^{3}<\mathrm{HF} 183<10^{5}$ copies / $100 \mathrm{~mL}$ ). In cluster IV, the presence of human bacteriophages (FRNAPH II) and the ruminant-specific Bacteroidales marker Rum-2-Bac suggested mixed pollution. Cluster $\mathrm{V}$ results also implied mixed pollution, with a high percentage of FRNAPH I, presence of the Rum-2-Bac marker and of the human chemical faecal markers. 
Legend Table 7: ${ }^{a}$ correspondence between abbreviations and names of markers is presented in Table $1 ;{ }^{b}$ no quantified. Limit of quantification were $<0.04 \mu \mathrm{g} / \mathrm{L}$ for caffeine, benzophenone and TCEP, $<0.01 \mu \mathrm{g} / \mathrm{L}$ for steroids used to calculate ratios R1 and R2, $<10$ PFU/100 mL for FRNAPH, $<1 \times 10^{3}$ gene copies or cells $/ 100 \mathrm{~mL}$ for bacterial markers; ${ }^{c}$ percentage were considered not representative when < 20 PFU isolates; ${ }^{d}$ not tested 
Table 7. Average concentrations of faecal indicators (microorganism $/ 100 \mathrm{~mL}$ ) and steroid $(\mu / L)$, ratios of steroids, percentage of FRNAPH genogroups and average concentrations of chemical markers $(\mu \mathrm{g} / \mathrm{L}$ ), of microbial markers (copies or cells/ $100 \mathrm{~mL}$ ) in WWPT effluent, runoff water and river water samples

\begin{tabular}{|c|c|c|c|c|c|c|c|c|c|c|c|c|c|c|c|c|c|c|}
\hline & & General & indicatc & & & MS & Mark & & & & & & & & & & & \\
\hline $\begin{array}{l}\text { Pollution } \\
\text { Origin }\end{array}$ & $\begin{array}{l}\text { Sample } \\
\mathrm{s}\end{array}$ & E. coli & AllBac $^{a}$ & FRNAPH & T. Steroids & R1 & R2 & Caff & Benzo & TCEP & $\begin{array}{l}\text { FR I-IV } \\
(\%)\end{array}$ & $\begin{array}{l}\text { FR II-III } \\
(\%)\end{array}$ & HF183 & B. ado & Pig-1 & Pig-2 & L. amy & Rum-2 \\
\hline \multirow{6}{*}{$\begin{array}{l}\text { WWTP } \\
\text { effluent }\end{array}$} & & $1.4 \times 10$ & & & & 75. & & & & & & & $7.2 \times 10$ & $1.9 \times 10$ & & & & \\
\hline & WW1 & & $1.1 \times 10^{8}$ & $1.2 \times 10^{3}$ & 3213 & 6 & 0.1 & 0.83 & 0.2 & 0.49 & 0 & 100 & & & - & - & - & $6.1 \times 10^{3}$ \\
\hline & WW2 & $2.3 \times 10$ & $1.0 \times 10^{8}$ & $1.7 \times 10^{3}$ & 2446 & 79 & $\begin{array}{l}0.0 \\
2\end{array}$ & 0.3 & 0.16 & 0.08 & 0 & 100 & $\frac{6.3 \times 10}{6}$ & $\frac{4.1 \times 10}{5}$ & $\frac{9.9 \times 10}{4}$ & - & - & 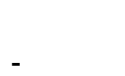 \\
\hline & & $6.3 \times 10$ & & & & 70. & 0.2 & & & & & & $4.4 \times 10$ & $7.1 \times 10$ & $1.8 \times 10$ & & & \\
\hline & WW3 & & $3.5 \times 10^{7}$ & $1.7 \times 10^{4}$ & 1356 & 5 & 4 & 1.27 & 0.2 & 0.16 & 21 & 79 & & & & - & - & - \\
\hline & WW4 & ${ }_{4}^{6.9 \times 10}$ & $1.8 \times 10^{6}$ & $3.4 \times 10^{3}$ & 1797 & $\begin{array}{l}61 . \\
4\end{array}$ & $\begin{array}{l}0.5 \\
2\end{array}$ & 0.33 & 0.27 & 0.3 & 71 & 21 & $\frac{3.1 \times 10}{6}$ & $\frac{1}{5} .8 \times 10$ & - & - & - & - \\
\hline \multirow[t]{7}{*}{ Cattle } & C1 & $\frac{1.9 \times 10}{4}$ & $6.1 \times 10^{6}$ & $-b$ & 18 & $\begin{array}{l}42 . \\
9\end{array}$ & 1.4 & - & - & - & $\mathrm{nd}^{\mathrm{c}}$ & nd & - & - & - & - & - & $3.6 \times 10^{5}$ \\
\hline & & $1.5 \times 10$ & & & & 38. & 1.7 & & & & & & & $3.2 \times 10$ & & & & \\
\hline & $\mathrm{C} 2$ & & $3.8 \times 10^{6}$ & - & 31 & 7 & 6 & - & - & - & nd & nd & - & & - & - & - & $3.0 \times 10^{5}$ \\
\hline & C3 & $\frac{1.7 \times 10}{4}$ & $8.5 \times 10^{6}$ & - & 30 & $\begin{array}{l}38 . \\
3\end{array}$ & 1.8 & - & - & - & nd & nd & - & $\begin{array}{l}4.9 \times 10 \\
4\end{array}$ & - & - & - & $5.9 \times 10^{5}$ \\
\hline & B1 & $\frac{1}{6} .1 \times 10$ & $5.9 \times 10^{9}$ & $4.6 \times 10^{2}$ & 145 & $\begin{array}{l}49 . \\
8\end{array}$ & $\begin{array}{l}2.3 \\
2.3\end{array}$ & - & - & - & $\mathrm{nt}^{\mathrm{d}}$ & nt & - & $\frac{2.8 \times 10}{5}$ & - & - & - & $1.9 \times 10^{7}$ \\
\hline & B2 & $\begin{array}{l}1.610^{5} \\
2.9 \times 10\end{array}$ & $1.2 \times 10^{8}$ & $1.1 \times 10^{3}$ & 118 & $\begin{array}{l}49 \\
48 .\end{array}$ & $\begin{array}{l}5 \\
2.1\end{array}$ & - & - & - & 0 & 22 & - & - & - & - & - & $8.8 \times 10^{6}$ \\
\hline & B3 & & $9.6 \times 10^{8}$ & $1.6 \times 10^{2}$ & 104 & 3 & 3 & - & - & - & nt & nt & - & - & - & - & - & $5.0 \times 10^{6}$ \\
\hline \multirow[t]{4}{*}{ Pig } & P1 & & $3.8 \times 10^{8}$ & - & 107 & $\begin{array}{l}57 . \\
4\end{array}$ & $\begin{array}{l}0.5 \\
9\end{array}$ & - & - & - & nd & nd & - & - & $\frac{1}{7} .3 \times 10$ & $\frac{1.0 \times 10}{6}$ & $4.5 \times 10^{7}$ & - \\
\hline & & $6.6 \times 10$ & & & & & 0.6 & & & & & & & & $4.4 \times 10$ & $7.3 \times 10$ & & \\
\hline & $\mathrm{P} 2$ & & $6.9 \times 10^{8}$ & - & 98 & 56 & 3 & - & - & - & nd & nd & - & - & & & $4.2 \times 10^{7}$ & - \\
\hline & P3 & $2.0 \times 10$ & $2.4 \times 10^{8}$ & - & 133 & 56 & $\begin{array}{l}0.6 \\
4\end{array}$ & - & - & - & nd & nd & - & - & $\frac{8.1 \times 10}{5}$ & $\frac{3.2 \times 10}{5}$ & $1.9 \times 10^{7}$ & - \\
\hline \multirow[t]{7}{*}{ Unknown } & & $1.7 \times 10$ & & & & 45. & 0.6 & & & & & & & & & & & \\
\hline & $\mathrm{R} 1$ & & $1.7 \times 10^{7}$ & 20 & 72 & 4 & 4 & 0.13 & 0.2 & 0.06 & 93 & 0 & - & - & - & - & - & $3.9 \times 10^{5}$ \\
\hline & $\mathrm{R} 2$ & $\frac{1.1 \times 10}{4}$ & $9.0 \times 10^{6}$ & 20 & 88 & $\begin{array}{l}50 . \\
5\end{array}$ & $\begin{array}{l}0.3 \\
9\end{array}$ & 0.14 & 0.17 & 0.06 & 44 & 56 & $2.0 \times 10$ & $4.6 \times 10$ & - & - & - & $1.6 \times 10^{5}$ \\
\hline & & $1.2 \times 10$ & & & & 45. & 0.7 & & & & & & $3.0 \times 10$ & $2.9 \times 10$ & & & & \\
\hline & R3 & & $1.1 \times 10^{7}$ & 66 & 38 & 3 & 6 & 0.14 & 0.08 & 0.08 & 63 & 37 & & & - & - & - & $1.7 \times 10^{5}$ \\
\hline & R4 & $\frac{1.2 \times 10}{4}$ & $2.2 \times 10^{7}$ & 50 & 41 & 55 & $\begin{array}{l}0.5 \\
3\end{array}$ & 0.17 & 0.16 & 0.09 & 44 & 56 & $3.6 \times 10$ & $3.3 \times 10$ & - & - & - & $1.1 \times 10^{5}$ \\
\hline & R5 & $5.5 \times 10$ & $6.3 \times 10^{6}$ & 66 & 55 & 42. & 0.8 & 1.99 & 0.14 & 0.08 & 53 & 47 & $2.3 \times 10$ & - & - & - & - & $2.9 \times 10^{5}$ \\
\hline
\end{tabular}




\begin{tabular}{|c|c|c|c|c|c|c|c|c|c|c|c|c|c|c|c|c|c|}
\hline & 3 & & & & 1 & 3 & & & & & & 3 & & & & & \\
\hline R6 & $\frac{1}{3} .5 \times 10$ & $7.5 \times 10^{6}$ & $6.0 \times 10^{2}$ & 39 & $\begin{array}{l}43 . \\
7\end{array}$ & $\begin{array}{l}0.5 \\
6\end{array}$ & 0.13 & 0.14 & - & 0 & 100 & $\frac{1}{4} .5 \times 10$ & - & - & - & - & $2.3 \times 10^{5}$ \\
\hline R7 & $\frac{2.2 \times 10}{3}$ & $1.2 \times 10^{7}$ & $4.8 \times 10^{2}$ & 63 & $\begin{array}{l}49 . \\
7\end{array}$ & $\begin{array}{l}0.4 \\
8\end{array}$ & 0.15 & - & - & 0 & 100 & $\frac{1}{4} .7 \times 10$ & $\frac{3.3 \times 10}{4}$ & - & - & - & $3.9 \times 10^{5}$ \\
\hline R8 & $2.5 \times 10$ & $7.6 \times 10^{6}$ & $5.8 \times 10^{2}$ & 60 & $\begin{array}{l}50 . \\
7\end{array}$ & $\begin{array}{l}0.4 \\
5\end{array}$ & 0.1 & 0.17 & - & 0 & 100 & ${ }_{4}^{5.1 \times 10}$ & - & - & - & - & $2.8 \times 10^{5}$ \\
\hline R9 & $\frac{1}{3} .7 \times 10$ & $1.4 \times 10^{7}$ & $5.5 \times 10^{2}$ & 38 & 47 & $\begin{array}{l}0.4 \\
5\end{array}$ & 0.14 & 0.12 & - & 0 & 100 & ${ }_{4}^{9.6} 6 \times 10$ & $\frac{7.4 \times 10}{3}$ & - & - & - & $3.2 \times 10^{4}$ \\
\hline R10 & $\frac{3}{3} .2 \times 10$ & $2.1 \times 10^{7}$ & $8.3 \times 10^{2}$ & 40 & 42 & $\begin{array}{l}0.5 \\
3\end{array}$ & 0.16 & 0.08 & - & 0 & 100 & ${ }_{4}^{9.2 \times 10}$ & ${ }_{4}^{4.4 \times 10}$ & - & - & - & $8.4 \times 10^{5}$ \\
\hline R11 & $\frac{3}{3} .2 \times 10$ & $1.0 \times 10^{6}$ & $3.2 \times 10^{2}$ & 13 & $\begin{array}{l}45 . \\
5 \\
56 .\end{array}$ & $\begin{array}{l}1.0 \\
1 \\
0.7\end{array}$ & 0.11 & - & - & 0 & 96 & $8.1 \times 10$ & $8.1 \times 10$ & - & - & - & - \\
\hline R12 & $\begin{array}{l}53 \\
5.0 \times 10\end{array}$ & $4.1 \times 10^{4}$ & - & 8 & 2 & $\begin{array}{l}6 \\
0.9\end{array}$ & 0.09 & - & - & 0 & 0 & nd & - & - & - & - & - \\
\hline R13 & $3.3 \times 10$ & $3.3 \times 10^{5}$ & - & 13 & $\begin{array}{l}51 \\
53 .\end{array}$ & $\begin{array}{l}6 \\
0.8\end{array}$ & 0.08 & - & - & nd & nd & nd & - & - & - & - & - \\
\hline R14 & & $9.0 \times 10^{4}$ & - & 16 & $\begin{array}{l}6 \\
50 .\end{array}$ & $\begin{array}{l}6 \\
1.0\end{array}$ & 0.08 & - & - & nd & nd & nd & - & - & - & - & - \\
\hline R15 & 34 & $5.1 \times 10^{5}$ & 30 & 15 & 1 & 3 & 0.2 & - & - & 0 & 0 & nd & - & - & - & - & - \\
\hline R16 & 32 & $3.5 \times 10^{3}$ & - & 12 & - & - & 0.07 & - & - & nd & nd & nd & - & - & - & - & - \\
\hline R17 & 63 & $5.3 \times 10^{3}$ & - & 12 & $\begin{array}{l}50 . \\
9 \\
50 .\end{array}$ & $\begin{array}{l}0.9 \\
9 \\
0.9\end{array}$ & 0.06 & - & - & nd & nd & nd & $\begin{array}{l}7.1 \times 10 \\
9.3 \times 10\end{array}$ & - & - & - & - \\
\hline R18 & 55 & $3.9 \times 10^{3}$ & 20 & 18 & $\begin{array}{l}1 \\
50 .\end{array}$ & $\begin{array}{l}7 \\
1.0\end{array}$ & 0.08 & - & - & 0 & 0 & nd & & - & - & - & - \\
\hline R19 & 41 & $5.1 \times 10^{4}$ & $<10$ & 23 & $\begin{array}{l}1 \\
50 .\end{array}$ & $\begin{array}{l}3 \\
1.0\end{array}$ & 0.07 & - & - & nd & nd & nd & - & - & - & - & - \\
\hline R20 & 41 & $5.9 \times 10^{3}$ & 10 & 25 & 6 & 1 & 0.09 & - & - & 25 & 16.7 & nd & - & - & - & - & - \\
\hline
\end{tabular}




\section{Discussion}

An efficient MST toolbox is crucial for identifying the origin of faecal pollution in water and is, therefore, essential for effective resource management and remediation. In this study, we compared a selection of chemical, bacterial and viral markers on water samples characterized by different faecal pollution loads. Some of these markers, such as hostspecific Bacteroidales and L. amylovorus, had previously been described and tested on faecal samples elsewhere (Bernhard and Field, 2000; Seurink et al, 2005; Mieszkin et al, 2009, 20010; Marti et al, 2010), whereas others, such as faecal steroids, chemical synthetic compounds, FRNAPH and Bifid. adolescentis, were developed or improved in the present study.

For faecal sterols, rather than considering individual concentrations of the 15 compounds investigated, we found that the use of two derived variables, i.e. the R1 and R2 ratios, was more efficient to distinguish human, bovine and porcine pollution. The results obtained with R1 were found similar to those obtained by Shah et al. (2007), who used this ratio to differentiate between animal manure, $(\mathrm{R} 1<45 \%)$ dominated by 24-ethylcoprostanol, and human manure (R1>60\%), dominated by coprostanol. The difference could be explained by the distributions of steroids: in bovine manure these are dominated by phytosteroids, whereas in WWTP effluents and porcine manures they are dominated by coprostanol (Leeming et al., 1996; Tyagi et al., 2007). The choice of the R2 ratio was based on the distribution of the steroid compounds in our samples of animal manure and WWTP effluents. This ratio allowed us to refine the differentiation between bovine manure (R2>1), porcine manure and WWTP effluent samples (R2<1).

The five selected chemical compounds tested were present in the WWTP effluents at similar levels as those previously reported (Ternes et al., 2001; Weigel et al., 2004; Glassemeyer et al., 2005). Only three chemical markers (caffeine, TCEP and benzophenone) were suitable for identifying human pollution in the environment, as these were detected not only in WWTP effluents but also in river waters impacted by human wastes.

Among the four genogroups of FRNAPH, only human-specific FRNAPH II could be could be used to trace specific pollution. Indeed, this genogroup, which was not detected in porcine, bovine or ovine faeces, was found in all of the $94.3 \%$ of WWTP effluent samples in which FRNAPH were detected, and made up approximately $60 \%$ of the FRNAPH isolated in these WWTP effluent samples. This group was also detected in some avian faeces, possibly because birds that inhabit beaches, picnic areas, and landfills come into contact with human wastes (Dick et al., 2005) and in 2 of the 30 bovine manure samples tested. The other FRNAPH genogroups were found to be less efficient. Thus, FRNAPH III, which represented only $17.4 \%$ of FRNAPH isolated in WWTP effluent samples, was also detected in porcine manure. Our results are in accordance with the data reported by Blanch et al. (2006), who detected this genogroup in $33 \%$ of animal effluent and farm manure samples. Although FRNAPH I was mainly present in bovine, porcine, ovine and avian faeces and in porcine manure, it was also found in WWTP effluents. This lesser specificity led Stapleton et al. (2007) to exclude FRNAPH I from their analyses. FRNAPH IV were found more specific but also less sensitive as they were only present in porcine faeces and manure and avian faeces samples and at a lot weaker percentages than FRNAPH I. Moreover, animal-specific FRNAPH (FRNAPH I and IV) were found particularly inefficient for tracing bovine pollution, as only 20 FRNAPH I were isolated from the 62 cow faeces and manure samples. A weak prevalence of FRNAPH in cow faeces has already been observed in other studies (Calci et al., 1998 ; Long et al., 2005).

No MST bacterial indicator has yet been demonstrated to be strictly human-specific. The human specificity of $B$. adolescentis has been much debated. Some consider it to be humanspecific (King et al., 2007), while others have detected it in pig (Dorai-Raj et al., 2009), cattle (Lamendella et al., 2008; Dorai-Raj et al., 2009) and poultry manure (Bonjoch et al., 2004). This study confirmed that, although the specificity of $B$. adolescentis for humans is high (94.5 
$\%$, it can also be found in some bovine and avian faeces. The new real-time PCR system we developed, however, seems more human-specific than the previous PCR system used for quantification of Bifid adolescentis by Dorai-Raj et al. (2009) and Bonjoch et al. (2004), since our results were negative for porcine samples and poultry manure. It should be underlined that Bifid. adolescentis was never detected in porcine manures in our study, and the concentrations in bovine manures were lower than those in treated effluents from WWTP urban sewage.

Microbial markers, Rum-2-Bac, Pig-2-Bac and L. amylovorus were only detected in water impacted by the respective manures, confirming host specificity, as observed by Mieszkin et al. $(2009,2010)$ and Marti et al. (2010). Furthermore, it is interesting to note that the humanspecific Bacteroidales marker HF183 was also found to be highly specific, in line with the successfully testing of specificity obtained in the EU with this marker (Seunrick et al., 2005; Mieszkin et al., 2009), in the USA by Kildare et al (2007) and in Australia by Ahmed et al. (2009).

MST toolboxes tested in previous studies essentially focused on microbial markers (Griffith et al., 2003, Blanch et al., 2006, Ahmed et al., 2007; MacQuaig et al., 2009). Thus, Griffith et al. (2003) compared the efficiency of phenotypic and genotypic analyses on E. coli, genotypic analysis on the Bacteroides / Prevotella group, typing of FRNAPH, and identification of human viruses. They concluded that the most specific method was the host-specific PCR. Ahmed et al. (2007) compared the efficiency of a library-dependent method using E. coli and enterococci with library-independent methods (host-specific PCR of Bacteroidales 16S rRNA gene markers and PCR of a human-specific Enterococcus surface protein marker), concluding that the library-independent methods were more sensitive than the librarydependent one. However, these two studies highlight the interest of combining different methods to enhance the identification of the origin of the faecal pollution. In accordance with these data, we selected only library-independent methods and our toolbox combined microbial and chemical markers including steroids. Steroids had been previously tested by Blanch et al. (2006) who found that, while coprostanol and 24-ethylcoprostanol were not sufficiently discriminating, the ratios sitostanol/coprostanol and coprostanol/coprostanol+24ethylcoprostanol were clearly different between human and animal samples. While Blanch et al. (2006), tested only wastewaters and slurries for their markers, we also evaluated marker efficiency on rivers, without a priori knowledge of the $E$. coli level. Our results clearly demonstrate the influence of the faecal pollution loads, as the 11 selected markers were only able to identify the source of pollution in waters when $E$. coli concentration was more than $5 \times 10^{2} / 100 \mathrm{~mL}$. Unlike Blanch et al. (2006), who studied the presence of their markers in several geographic areas in Europe, our sampling was performed only in France. It should be noted, however, that many of our markers have been detected in other countries by other studies: L. amylovorus (Konstantinov et al, 2006; Pieper et al., 2008, Su et al., 2008), HF183 (Bernard and Field, 2000; Seurink et al, 2005; Ahmed et al, 2007), B. adolescentis (King et al., 2007; Lamendella et al.,2008); FRNAPH II (Blanch et al., 2006), the steroids (Leeming et a, 1996; Shah et al., 2007) and the synthetic compounds (Glassmeyer et al, 2005), pointing to the universal distribution of these markers. 


\section{Conclusion}

In conclusion, among the 17 MST markers investigated in this study, seven host-specific markers (caffeine, TCEP, benzophenone and bacterial markers HF183, Pig-2-Bac, Rum-2$B a c$ and $L$. amylovorus) and the two steroid ratios were found to be the most efficient for discriminating the origin of the faecal pollution. Bifid. adolescentis and FRNAPH II, which were slightly less discriminating, could make useful complementary markers.

Although knowledge is lacking on the persistence of the different types of markers (chemical, viral and bacterial) in environmental waters, our results show that when the level of faecal pollution is sufficiently high (i.e. $>500 \mathrm{E}$. coli / $100 \mathrm{~mL}$ ), the origin of the pollution can be determined using the set of markers tested in this study.

More precisely, to trace the origin of the faecal pollution, we recommend:

- For human pollution, the use of caffeine, TCEP and benzophenone, the steroid ratios sitostanol/coprostanol (R1) <60\% and coprostanol/coprostanol+24-ethylcoprostanol (R2) > 1, real-time PCR bacterial markers (HF183 and Bifid. adolescentis) and genotype II of FRNAPH,

- For porcine pollution, the use of steroid ratios $(\mathrm{R} 1<60 \%$ and $\mathrm{R} 2<1)$ and real-time $\mathrm{PCR}$ bacterial marker Pig-2-Bac and L. amylovorus,

- For ruminant pollution, the use of steroid ratios $(\mathrm{R} 1<60 \%$ and $\mathrm{R} 2>1)$ and real-time $\mathrm{PCR}$ bacterial marker Rum-2-Bac.

To improve confidence in these MST markers, the next steps should be to compare their persistence in river or marine waters and to apply them at the level of a catchment with a variety of pollution sources.

Finally, when established, these analysis methods will be transferred to water analysis laboratories. Such laboratories are increasingly required to identify the origin of water pollution, particularly to assist with the management of microbial water quality of bathing and shellfish farming areas and to establish bathing water profiles. 


\section{Acknowledgements}

This work received funding from AFSSET (Agence Française de Sécurité Sanitaire Environnementale et du Travail, EST-2006/1/36). Romain Marti, Sophie Mieszkin and Morgane Derrien received Cemagref-Ademe, Ifremer-Région Bretagne and CNRS-Région Bretagne fellowships, respectively. We thank $\mathrm{H}$. McCombie-Boudry for re-reading the manuscript. We also thank C. Le Mennec and C. Marin for their technical assistance.

\section{References}

Ahmed, W., Stewart, J., Gardner, T., Powell, D., Brooks, P., Sullivan, D., Tindale, N., 2007. Sourcing faecal pollution: A combination of librarydependent and library-independent methods to identify human faecal pollution in non-sewered catchments. Water Research 41 (16), 3771-3779.

Ahmed, W., Goonetilleke, A., Gardner, T., Powell, D., 2009. Evaluation of multiple sewageassociated Bacteroides PCR markers for sewage pollution tracking. Water Research 43 (19), $4872-4877$.

Anonyme. 2001. NF EN ISO 10705-1. Water quality. Detection and enumeration of bacteriophages. Part 1: Enumeration of $F$ specific RNA bacteriophages.

AFNOR, december 1999. Norme XP T 90-210 Protocol for evaluating a chemical method for quantitative comparison with a reference method.

Beekwilder, J., Nieuwenhuizen, R., Havelaar, A.H. and van Duin, J. (1996) An oligonucleotide hybridization assay for the identification and enumeration of F-specific RNA phages in surface water. Journal of Applied Bacteriology 80(2), 179-186.

Bernhard, A.E. and Field, K.G. (2000) A PCR assay to discriminate human and ruminant feces on the basis of host differences in Bacteroides-Prevotella genes encoding 16S rRNA. Applied and Environmental Microbiology 66(10), 4571-4574.

Blanch, A R., Belanche-Munoz, L., Bonjoch, X., Ebdon, J., Gantzer, C., Lucena, F., Ottoson, J., Kourtis, C., Iversen, A., Kuhn, I., Moce, L., Muniesa, M., Schwartzbrod, J., Skraber, S., Papageorgiou, G.T., Taylor, H., Wallis, J. and Jofre, J. (2006) Integrated analysis of established and novel microbial and chemical methods for microbial source tracking. Applied and Environmental Microbiology 72(9), 5915-5926.

Bonjoch, X., Ballesté, E. and Blanch, A.R. (2004) Multiplex PCR with 16S rRNA genetargeted primers of Bifidobacterium spp. to identify sources of fecal pollution. Applied and Environmental Microbiology 70(5), 3171-3175.

Calci, K.R., Burkhardt, W. III, Watkins, W.D., Rippey, S.R., 1998. Occurrence of malespecific bacteriophages in feral domestic animal wastes, human feces, and human-associated wastewaters. Applied and Environmental Microbiology 64 (12), 5027-5029.

Delcenserie, V., Bechoux, N., Leonard, T., China, B. and Daube, G. (2004) Discrimination between Bifidobacterium species from human and animal origin by PCR-restriction fragment length polymorphism. Journal of Food Protection 67(6), 1284-1288

Dick, L.K., Bernhard, A.E., Brodeur, T.J., Santo Domingo, J.W., Simpson, J.M., Walters, S.P. and Field, K.G. (2005) Host distribution of uncultivated fecal Bacteroidales bacteria reveal genetic markers for fecal source identification. Applied and Environmental Microbiology 71(6), 3184-3191.

Dorai-Raj, S., O'Grady, J. and Colleran, E. (2009) Specificity and sensitivity evaluation of novel and existing Bacteroidales and Bifidobacteria-specific PCR assays on feces and sewage samples and their application for microbial source tracking in Ireland. Water Research 43(19), 4980-4988. 
Dorfman, M. and Sinclair Rosselot, K. (2008) Testing the Waters 2008: a Guide to Water Quality Testing at Vacation Beaches. Washington, DC: Natural Resources Defense Council. Feldhusen, F. (2000) The role of seafood in bacterial foodborne disease. Microbes and Infection 2(13), 1651-1660.

Field, K.G. and Samadpour, M. (2007). Fecal source tracking, the indicator paradigm, and managing water quality. Water Research 41(16), 3517-3538.

Gawler, A.H., Beecher, J.E., Brandao, J., Carroll, N., Falcao, L., Gourmelon, M., Masterson, B., Nunes, B., Porter, J., Rincé, A., Rodrigues, R., Thorp, M., Walters, J.M. and Meijer, W.G. (2007) Validation of host-specific Bacteriodales 16S rRNA genes as markers to determine the origin of faecal pollution in Atlantic Rim countries of the European Union. Water Research 41(16), 3780-3784.

Germond, J.E., Mamin O. and Mollet, B., (2002) Species specific identification of nine human Bifidobacterium spp. in feces. Systematic and Applied Microbiology 25, 536-543.

Glassmeyer S.T., Furlong ET., Kolpin D.W., Cahill J.D., Zaugg S.D., Werner S.L., Meyer M.T. and Kryak, D.D. (2005) Transport of chemical and microbial compounds from known wastewater discharges: potential for use as indicators of human fecal contamination. Environmental Science and Technology 39(14), 5157-5169.

Griffith, J.F., Weisberg, S.B. and McGee, C.D. (2003) Evaluation of microbial source tracking methods using mixed fecal sources in aqueous test samples. Journal of Water and Health 1 , 141-151.

Jardé, E., Gruau, G., Mansuy-Huault, L., 2007. Detection of manure-derived organic compounds in rivers draining agricultural areas of intensive manure spreading. Applied Geochemistry 22 (8), 1814-1824

Jardé, E., Gruau, G. and Jaffrezic, A. (2009) Tracing and quantifying sources of fatty acids and steroids in amended cultivated soils. Journal of Agricultural and Food Chemistry 57(15), 6950-6956.

Jimenez-Clavero, M.A., Fernandez, C., Ortiz, J.A., Pro, J., Carbonell, G., Tarazona, J.V., Roblas, N. and Ley, V. (2003) Teschoviruses as indicators of porcine fecal contamination of surface water. Applied and Environmental Microbiology 69(10), 6311-6315.

Kildare, B.J., Leutenegger, C.M., McSwain, B.S., Bambic, D.G., Rajal, V. and Wuertz, S. (2007) 16S rRNA-based assays for quantitative detection of universal, human-, cow-, and dog-specific faecal Bacteroidales: A Bayesian approach. Water Research 41(16), 37013715.

King, E.L., Bachoon, D.S. and Gates, K.W. (2007) Rapid detection of human fecal contamination in estuarine environments by PCR targeting of Bifidobacterium adolescentis. Journal of microbiological methods 68(1), 76-81.

Konstantinov, S.R., Smidt, H. and de Vos, W.M. (2005) Representational Difference Analysis and Real-Time PCR for Strain-Specific Quantification of Lactobacillus sobrius sp. nov. Applied and Environmental Microbiology 71(11), 7578-7581.

Lamendella, R., Santo Domingo, J.W., Kelty, C. and Oerther, D.B. (2008) Bifidobacteria in feces and environmental waters. Applied and Environmental Microbiology 74(3), 575- 584.

Layton, A., McKay, L., Williams, D., Garrett, V., Gentry, R. and Sayler, G. (2006) Development of Bacteroides 16S rRNA gene TaqMan-based real-time PCR assays for estimation of total, human, and bovine fecal pollution in water. Applied and Environmental Microbiology 72(6), 4214-4224.

Leeming, R., Bal,I A., Asholt, N. and Nichols, P.D. (1996) Using faecal sterols from humans and animals to distinguish faecal pollution in receiving waters. Water Research, 30(12), 2893-2900.

Long, S. C., El-Khoury, S. S., Oudejans, S.J.G., Sobsey, M.D., Vinje. J., 2005. Assessment of sources and diversity of male-specific coliphages for source tracking. Environmental Engineering Science 22 (3) 367-377.

Lu, J., Santo Domingo, J.W., Lamendella, R., Edge, T., Hill, S., 2008. Phylogenetic diversity and molecular detection of bacteria in gull feces. Applied and Environmental Microbiology 74 (13), 3969-3976. 
Marti, R., Dabert, P. and Pourcher, A.M. (2009) Selection of a pig manure contamination marker based on the influence of biological treatment on the dominant faecal microbial groups. Applied and Environmental Microbiology 75(15), 4967-4974.

Marti, R., Dabert, P., Ziebal, C. and Pourcher, A.M. (2010) Evaluation of Lactobacillus sobrius/amylovorus as a new microbial marker of pig manure. Applied and Environmental Microbiology 76(5), 1456-1461.

Mieszkin, S., Furet, J.P., Corthier, G. and Gourmelon, M. (2009) Estimation of pig fecal contamination in a river catchment by Real-Time PCR using two pig-specific Bacteroidales 16S rRNA genetic markers. Applied and Environmental Microbiology 75(10), 3045-3054.

Mieszkin, S., Yala, J.F., Joubrel, R. and Gourmelon, M. (2010) Phylogenetic analysis of Bacteroidales 16S rRNA gene sequences from human and animal effluents and assessment of ruminant faecal pollution by real-time PCR. Journal of Applied Microbiology 108(3), 974984.

Ogorzaly, L., and Gantzer, C. (2006) Development of real-time RT-PCR methods for specific detection of F-specific RNA bacteriophage genogroups: Application to urban raw wastewater. Journal of Virological Methods 138(1-2), 131-139.

Ogorzaly, L., Tissier, A., Bertrand, I., Maul, A. and Gantzer, C. (2009) Relationship between F-specific RNA phage genogroups, faecal pollution indicators and human adenoviruses in river water. Water Research 43(5), 1257-1264.

Pieper, R., Janczyk, P., Zeyner, A., Smidt, H., Guiard, V., Souffrant, W. B., 2008. Ecophysiology of the developing total bacterial and Lactobacillus communities in the terminal small intestine of weaning piglets. Microbial Ecology 56 (3) 474-483.

Rabinovici, S.J., Bernknopf, R.L., Wein, A.M., Coursey, D.L. and Whitman, R.L. (2004) Economic and health risk trade-offs of swim closures at a Lake Michigan beach. Environmental Science and Technology 38(10), 2737-2745.

Regulation (EC) N $\mathrm{N}^{\circ} 854 / 2004$ of European Parliament and of the council of 29 april 2004. Laying down specific rules for the organisation of official controls on products of animal origin intended for human consumption. Official Journal of the European Union L139.

SANCO/825/00 rev.7. Guidance document on residue analytical methods.

Savichtcheva, O., Okayama, N., Okabe, S., 2007. Relationships between Bacteroides 16S rRNA genetic markers and presence of bacterial enteric pathogens and conventional fecal indicators. Water Research 41 (16) 3615-3628.

Schaper, M., Jofre, J., Uys, M. and Grabow, W.O. (2002) Distribution of genotypes of Fspecific RNA bacteriophages in human and non-human sources of faecal pollution in South Africa and Spain. Journal of Applied Microbiology 92 (8), 657-667.

Seurinck, S., Defoirdt, T., Verstraete, W. and Siciliano, S.D. (2005) Detection and quantification of the human-specific HF183 Bacteroides 16S rRNA genetic marker with realtime PCR for assessment of human faecal pollution in freshwater. Environmental Microbiology 7(2), 249-259.

Shah, V.G., Dunstan, R.H., Geary, P.M., Coombes, P., Roberts, T.K. and Von NagyFelsobuki, E. (2007) Evaluating potential applications of faecal sterols in distinguishing sources of faecal contamination from mixed faecal samples. Water Research 41(16), 36913700.

Stapleton, C.M., Wyer, M.D., Kay, D., Crowther, J., Mc Donald, A.T., Walters, M., Gawler, A. and Hindle, T. (2007) Microbial source tracking: a forensic technique for microbial source identification? Journal of Environmental Monitoring 9, 427-439.

Su, Y., Yao, W., Perez-Gutierrez, O. N., Smidt, H., Zhu. W. Y., 2008. Changes in abundance of Lactobacillus spp. and Streptococcus suis in the stomach, jejunum and ileum of piglets after weaning. FEMS Microbiology Ecology 66 (3) 546-555.

Ternes, T., Bonerz, M. and Schmidt, T. (2001) Determination of neutral pharmaceuticals in wastewater and rivers by liquid chromatography - electrospray tandem mass spectrometry. Journal of Chromatography A 938 (1-2), 175-185

Tyagi, P., Edwards, D.R. and Coyne, M.S. (2007) Use of selected chemical markers in combination with a multiple regression model to assess the contribution of domesticated animal sources of faecal pollution in the environment. Chemosphere 69(10), 1617-1624. 
Ufnar, J.A., Ufnar, D.F., Wang, S.Y. and Ellender, R.D. (2007) Development of a swinespecific fecal pollution marker based on host differences in methanogen mcrA genes. Applied and Environmental Microbiology 73(16), 5209-5217.

USEPA. 2005. Microbial Souce Tracking Guide Document DC EPA-600/R-05/064. Office of Researche and Development.

Weigel, S., Berger, U., Jensen, E., Kallenborn, R., Thoresen, H. and Hühnerfuss, H. (2004). Determination of selected pharmaceuticals and caffeine in sewage and seawater from Tromsø/Norway with emphasis on ibuprofen and its metabolites. Chemosphere 56(6), 583592.

Wéry, N., Monteil, C., Pourcher, A.M. and Godon, J.J. (2010) Human-specific fecal bacteria in wastewater treatment plant effluents. Water Research 44(6), 1873-1883.

Zaugg, S.D., Smith, S.G., Schroeder, M.P., Barber, L.B., and Burkhardt, M.R., 2002, Methods of analysis by the U.S. Geological Survey National Water Quality Laboratory-Determination of wastewater compounds by polystyrene-divinylbenzene solid-phase extraction and capillary-column gas chromatography/mass spectrometry: U.S. Geological Survey Water-Resources Investigations Report 01-4186, 37 p. 